\title{
New Record of Stinging Catfish, Heteropneustes microps (Gunther, 1864) from Vellayani Fresh Water Lake, Kerala, Southwest Coast of India
}

\author{
Reenamole, G. R. ${ }^{1}$, Ambili, T. ${ }^{2}$ \\ Department of Zoology, Zoology Research Centre, F. M. N. C., University of Kerala
}

\begin{abstract}
This paper documents the first record of the occurrence of stinging catfishes in Vellayani Freshwater Lake at Thiruvananthapuram district, Kerala, the southern part of Western Ghats region, which are native to Asia and endemic to Sri Lanka. Vellayani Lake, an important wetland in south India, is a natural habitat of waterfowls and the livelihood of about 100 traditional fishermen depends on the fish resources of this lake. The one year fish diversity study from June 2013 to May 2014, revealed the occurrence of the stinging catfish in the lake. The morphological taxonomy proved that the specimen is Heteropneustes microps, Gunther, 1864 (Nelson, J.S, 1994; Allaby, M, 1991; Arunachalam et al., 1999; U Fowler 1937; Devi and Raghunathan, 1999; Easa \& Shaji, 2003; Hubbs \& Lagler, 2004) of the family Heteropneustidae. About 42 species of freshwater fishes have been documented from the lake by various authors, primarily from the Department of Aquatic Biology and Fisheries, University of Kerala (Biju Kumar et. al, 2013). From Heteropneustidae family, Heteropneustes fossilis (Bloch, 1794) had already been identified as the native of this lake. Another species, Heteropneustes microps (Gunther, 1864) is reported for the first time from this second largest fresh water lake in Kerala.
\end{abstract}

Keywords: Heteropneustidae, airsac catfishes, Heteropneustes microps, Vellayani Freshwater Lake

\section{Introduction}

The stinging catfishes, Heteropneustes spp. of family Heteropneustidae, are native to Asia, distributed in freshwater habitats of Bangladesh, India, Myanmar, Nepal, Pakistan, Sri Lanka, Thailand and Vietnam (Berra, 2007). According to Froese Rainer and Pauly Daniel (2011), Heteropneustes microps is a species of airsac catfish possibly endemic to Sri Lanka, though records from India have been made. These are inhabited in ponds, ditches, canals, flooded rice fields, swamps, marshes, waterlogged areas and rivers of India. Arunachalam et al. (1999) described the occurrence and morphology of $H$. microps from Western Ghats, India. In Kerala, H. microps is first recorded by Arunachalam et al. (1999) from Northern Kerala. It is reported by Easa \& Shaji (2003) from inland waters of Trissur and Mananthavadypuzha in Wayanad from Kerala.

H. microps is a peculiar looking and an air-breathing freshwater fish (Pethiyagoda, R. 1994). Pethiyagoda, R. (1991) said that it inhabits both fresh and brackish waters. A long air sac acts like a lung that extends back from the gill chamber and enables the catfish to breathe air (Nelson, J.S. (1994). The air breathing apparatus enables the fish to survive in low water depth, even in turbid and oxygen deficit conditions. This fish is also known as stinging catfish. This fish is a component of local commercial fisheries, as well as being found in the aquarium trade (Froese, Rainer and Pauly, Daniel, eds. 2011). These are commercially important due to high market price and nutritional value that is low fat content and source of high amount of iron and calcium.

Up to date, only $H$. fossilis (Fig. 2) is reported from Vellayani Freshwater Lake, in Kerala, Thiruvananthapuram (Biju Kumar and Pramod Kiran, 2013). In this study, a fish biodiversity survey during 2013 June - 2014 May, observed that two species of Heteropneustes occurred in the freshwater ecosystem of Vellayani Lake, clearly described as H. microps is a new species, reported for the first time from this lake.

\section{Materials and Methods}

\subsection{Study Area}

The Vellayani Freshwater Lake $\left(8^{\circ} 24^{\text {ee }} 09^{\prime \prime}-8^{\circ} 26^{\text {ee }} 30^{\prime \prime} \mathrm{N}\right.$ and $76^{\circ} 59^{\text {"e }} 08^{\prime \prime}-76^{\circ} 59^{\circ e} 47^{\prime \prime}$ E) Thiruvananthapuram District in Kerala (Fig.1), is located $19 \mathrm{~km}$ away from the Thiruvananthapuram city. The Lake is situated 29 meters above mean sea level with a length of $3.15 \mathrm{~km}$ and width of $1 \mathrm{~km}$. The depth of the lake varies from 2 to $6 \mathrm{~m}$. The lake is a rich repository of flora and fauna which support the livelihood of local people around it. The livelihood of about 100 traditional fishermen depends on the fish resources of the lake. Vellayani Lake is an important wetland in south India used by waterfowls, both as feeding and breeding grounds.

\subsection{Sample Collection}

During a fish biodiversity survey of Vellayani Freshwater Lake, observed a phenotypically different stinging catfish among catches of local fishers. Samples were collected using „Pattu Vala ${ }^{e e}$, a type of seine net; during night. The adult specimens of this species were collected and brought to the Laboratory for taxonomic identification. Previously published descriptions available from the internet and the standard keys of Easa \& Shaji, 2003 and Biju Kumar and Pramod Kiran, 2013, were used to make comparison with the newly described species. Further identification up to species level was carried out using the distinguishing characteristics provided by Nelson, J.S, 1994; Allaby, M, 1991; Arunachalam et al., 1999; U Fowler 1937; Devi and Raghunathan, 1999. Measurements were taken follow the keys of Hubbs \& Lagler, 2004. The identified specimen is 


\section{International Journal of Science and Research (IJSR) \\ ISSN (Online): 2319-7064 \\ Index Copernicus Value (2013): 6.14 | Impact Factor (2014): 5.611}

preserved at the Laboratory of the Fatima Mata National College, Kollam, under the University of Kerala.

LOCATION MAP

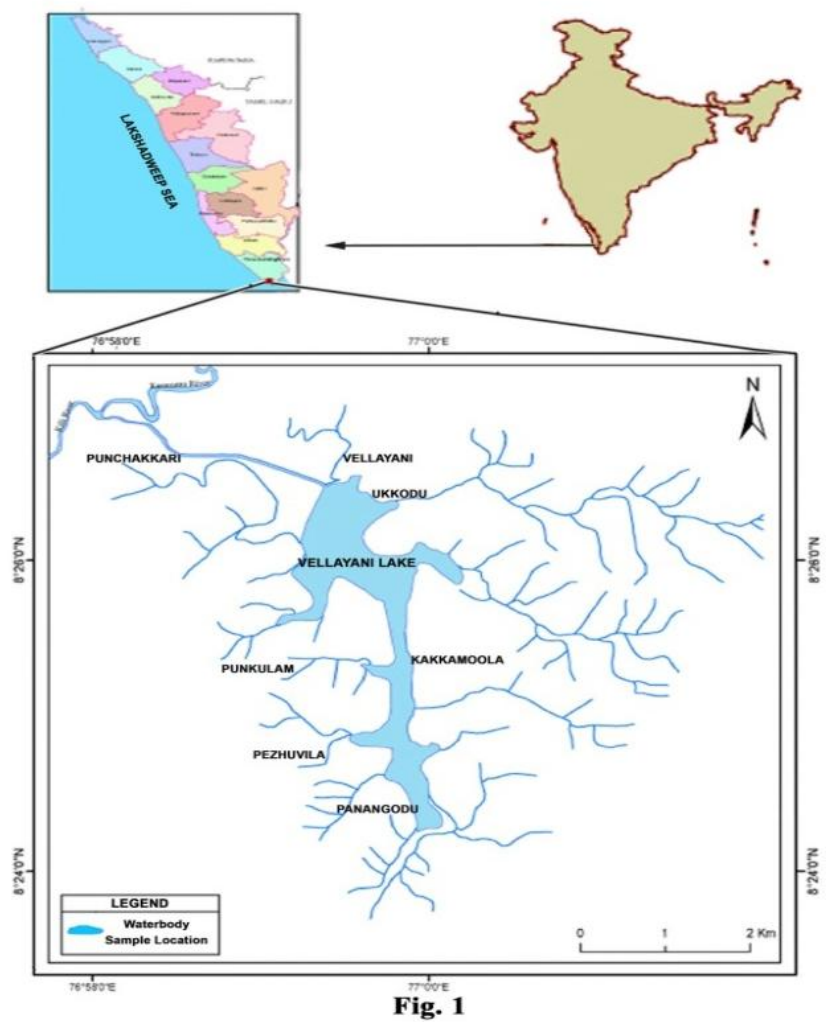

Figure 1: Map of the Vellayani Freshwater Lake

\section{Results and Discussions}

The oviparous, airsac catfishes are in the genus of Heteropneustes (J. P. Muller, 1840) and are native to Asia. This genus is the only one in its family Heteropneustidae (Nelson, 2006). The tiny sized, airsac catfish are dreaded by local fisherman due to the sharp poisonous spine in each pectoral fin that can inflict a painful sting on any person wading in its territory (Nelson, J.S, 1994; Allaby, M, 1991). The pectoral fins also have an associated venom gland and are considered dangerous. The sample fish was confirmed as the genus Heteropneustes, based on the following characters (Nelson, J.S, 1994; Allaby, M, 1991; and Easa \& Shaji, 2003).

- Their bodies are elongated and compressed with greatly depressed heads.

- Four pairs of barbels (fleshy projections) protrude from around the mouth.

- The dorsal fin is short and has no spine.

- A long anal fin on the rear underside of the body, and a rounded tail fin.

- In each pectoral fin has the sharp poisonous spine

- They have long air sacs that serve as lungs that extend from the gill chamber.

Ferreris (2007) and Hossain et. al (2013) described five nominal species of Heteropneustes genus are Heteropneustes fossilis (Bloch, 1794) from Tamil Nadu of India, H. microps (Gunther, 1864) from Dambuwa of Sri Lanka, $H$. Kemratensis (Fowler, 1937) from the Chao Praya River of Thailand, H. longipectoralis (Devi \& Raghunathan, 1999) from Western Ghats of India and Heteropneustes nani (Hossain, Sarker, Sharifuzzaman \& Chowdhury, 2013) from Noakhali, Bangladesh. The sample specimen was identified as Heteropneustes microps Gunther, 1864 (Fig.2) as per the keys provided by Nelson, J.S, 1994; Allaby, M, 1991; Arunachalam et al., 1999; U Fowler 1937; Devi and Raghunathan, 1999.

Key to species of $H$. fossilis and $H$. Microps are given below (U Fowler 1937; Arunachalam et al., 1999; Devi and Raghunathan, 1999).

- Body yellow or dark purplish-brown in above and lighter in ventral side, extended backward mouth, pectoral spine attached to rays by membrane with 3-4 antrorse serrae along inner edge at anterior tip, and separated anal-caudal fin by a distinct notch [Tamil Nadu, India] H. fossilis

- Body depth equals to head length, terminal mouth with well developed lips, pectoral spine separated from rays and serrated along inner edge, and anal fin confluent with caudal without notch [Dambuwa, Sri Lanka] H. microps 


\section{International Journal of Science and Research (IJSR) \\ ISSN (Online): 2319-7064}

Index Copernicus Value (2013): 6.14 | Impact Factor (2014): 5.611

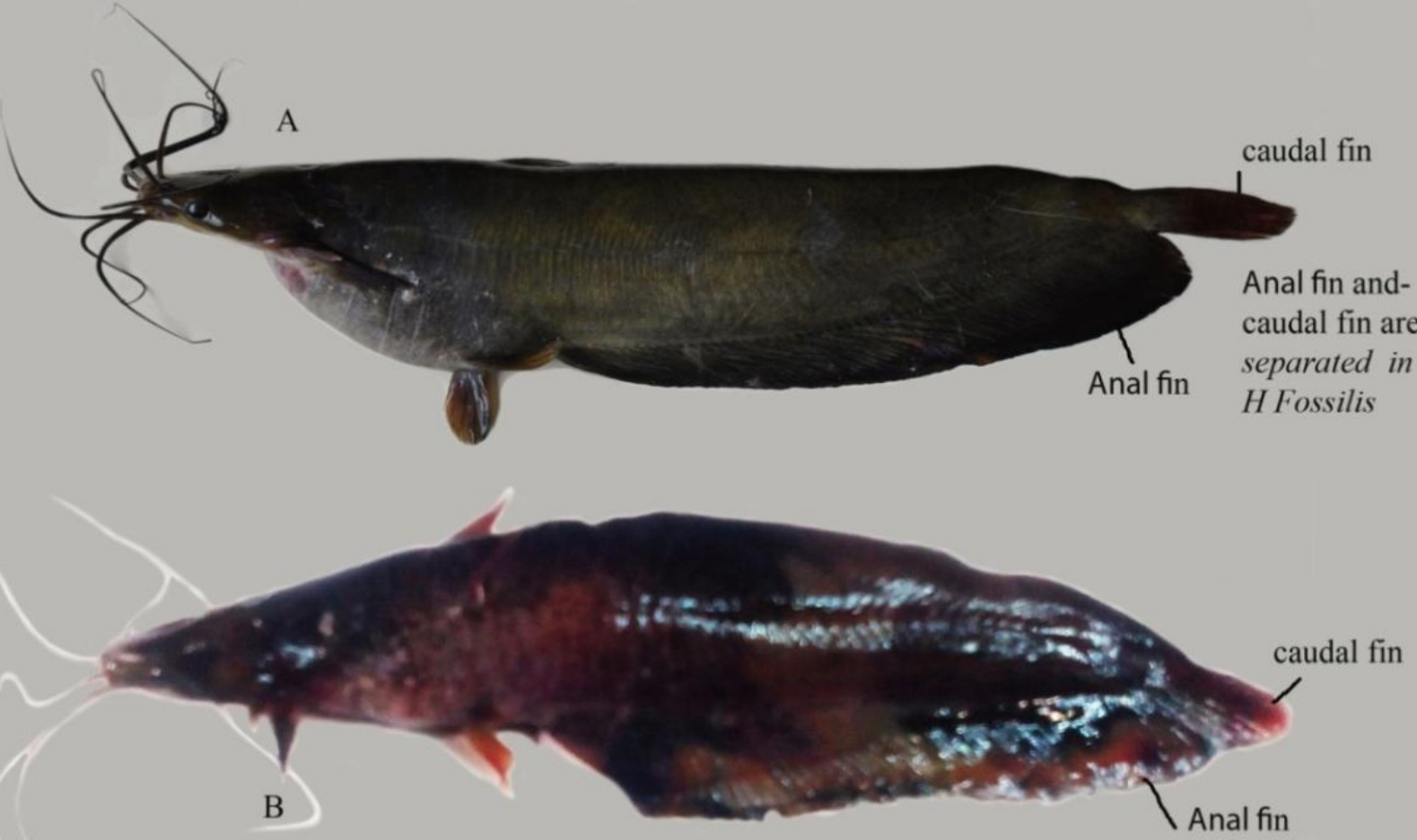

Anal fin of $H$. microps is confluent with the caudal fin

Figure 2: (A). Heteropneustes fossilis (B). Heteropneustes microps. Anal fin of H. microps is confluent with the caudal fin and separated in H. Fossilis

Pethiyagoda \& Bahir (1998) suggested H. microps as synonymous to $H$. fossilis, because the occurrence of fused conjoined anal and caudal fins, which is a distinct character of $H$. microps, may arise in wild populations (2\%) of Heteropneustes due to an injury. This observation proved to be redundant by Arunachalam et al. (1999). However, $H$. fossilis and $H$. microps are the two widely recognized species and the former is better known (Berra, 2007; Nelson, 2006). According to him, the Synonyms of $H$. fossilis are Silurus fossilis (Bloch, 1794); Silurus singio (Hamilton-Buchanan, 1822); Saccobranchus singio (Cuvier \& Valenciennes, 1831) and Saccobranchus fossilis (Muller \& Henle, 1837; Gunther, 1864; Day, 1878). The Synonym of $H$. microps is Saccobranchus microps (Gunther, 1864; Day, 1878). The sample specimen was identified as Heteropneustes microps, based on the following charecters.

- The sample fishes have the Total length (TL) of 13.7-15.5 centimetres.

- Body is dark brown.

- Ventral surface is lighter.

- The pectoral spine is Separated from rays and serrated along inner edge.

- Anal fin confluent with caudal without notch (Fig.2)

- Body depth equals to head length (3.5-3.7cm)

- terminal mouth with well developed lips

\begin{tabular}{lcl}
\multicolumn{2}{l}{ Systematic Position of the $\boldsymbol{H}$. microps } \\
Kingdom & $:$ & Animalia \\
Phylum & $:$ & Chordata \\
Grade & $:$ & Pisces \\
Class & $:$ & Actinopterygii \\
Order & $:$ & Siluriforms \\
Family & $:$ & Heteropneustidae
\end{tabular}

$\begin{array}{lll}\text { Genus } & : & \text { Heteropneustes } \\ \text { Species } & : & \text { microps }\end{array}$

Common name: Stinging catfish, Airsac catfish, Kleiner Speichenwels (Germany)

This airsac catfish has been found in an area heavily modified by man, where it inhabits swamps and similar still, often turbid waters, such as irrigation ditches (Pethiyagoda, R. 1994). They form loose schools of about ten individuals of approximately the same size. They enter brackish water. They can survive temperatures up to $39.8 \mathrm{~A}^{\circ} \mathrm{C}$. It inhabits both fresh and brackish waters (Pethiyagoda, R. 1991). In South-western Sri Lanka, where the airsac catfish has been found, is known as the ,wet zone ${ }^{e e}$ because it has an additional monsoon to the rest of the country (Pethiyagoda, R. 1994). Best method of catch is dewatering of small water holes during drought period (Froese, R. and D. Pauly, 2013).

$H$. microps species are omnivore with nocturnal feeding habits. In dorsal or ventral view of females are much broader in the body than males of equal age and rearing practices (Pethiyagoda, R. 1991). They are oviparous and distinct pairing is possible (Nelson, 2006). They are sympatric with $H$. fossilis which is more abundant in the type locality (Froese, R. and D. Pauly, 2013).

This is a venomous fish. Incidentally, this type of fish is able to deliver a stinging protein, known as ,poison or originated from the venom glands around the pectoral spine (Satora et al., 2005). Reports exist of fatal encounters between humans and it in the wild. Realistically it should come with a "buyers beware" sticker (Rohan Pethiyagoda and Mohomed M. Bahir, 1998). In humans, catfish venoms, which are reported to be

\section{Volume 5 Issue 3, March 2016}




\section{International Journal of Science and Research (IJSR) \\ ISSN (Online): 2319-7064 \\ Index Copernicus Value (2013): 6.14 | Impact Factor (2014): 5.611}

neurotoxic and hemolytic that is destruction of red blood cells, can produce local numbness, inflammation and severe painful physical conditions of the limb under attack (Wright, 2009). Warm water bath, application of luke warm turmeric paste, ejection of blood, and traditional herbal medicine are commonly used for healing. Local fishers remain extremely cautious to avoid its sting (Hossain et al., 2013).

\section{Conclusion}

This airsac catfish is classified as Vulnerable (VU) on the IUCN Red List. There are no known conservation measures currently in place for the vulnerable airsac catfish. It is recommended that the monitoring and conservation of this species.

\section{References}

[1] Allaby, M. (1991): The Concise Oxford Dictionary of Zoology. Oxford University Press, Oxford.

[2] Arunachalam, M.; Johnson, J.A. \& Manimekalan, A. (1999). New record of Heteropneustes microps (Günther) (Clariidae: Heteropneustidae) from Western Ghats Rivers, India. - Journal of Bombay natural history society, 96(2): $330-332$.

[3] Berra, T.M. (2007). Freshwater fish distribution, The University of Chicago Press: Chicago, USA.

[4] Biju Kumar, A and Pramod Kiran, R.B., (2013): Fish Diversity of Vellayani Lake: A Field Guide, Dept of AQB and Fisheries, University of Kerala, Karyavattom, TVPM.

[5] Cuvier, G.L.C.F.D. \& Valenciennes, A. (1831). Histoire naturelle des poissons, Vol. 7, Levrault, Paris and Strasbourg, $531 \mathrm{pp}$.

[6] Devi, K.R. \& Raghunathan, M.B. (1999). Heteropneustes longipectoralis (Siluriformes: Heteropneustidae) a new species from the Anamalai Hills, in the western Ghats. Records of the Zoological Survey of India, 97(3): 109 115.

[7] Easa, P.S and C. P. Shaji.,( 2003): Division of Wildlife Biology, Biodiversity Documentation for Kerala, Part 8: Freshwater Fishes, K.F.R.I., An Instruction of State Council for Science, Technology and Environment Peechi, Kerala, India.

[8] Ferreris, C.J. Jr. (2007). Checklist of catfishes, recent 1. and fossil (Osteichthyes: Siluriformes), and catalogue of Siluriform primary types, Zootaxa 1418, Magnolia Press, Auckland, New Zealand, 628 pp.

[9] Fowler, H.W. (1937). Zoological results of the third De Schauensee Siamese Expedition, Part VIII - Fishes obtained in 1936. - Proceedings of the Academy of natural Sciences of Philadelphia, 89: 125 - 264.

[10] Froese, R. and D. Pauly. Editors. 2013. FishBase. World Wide Web electronic publication.; http://www.fis...

[11] Froese, Rainer and Pauly, Daniel, eds. (2011). "Heteropneustes microps" in FishBase. December 2011 version.

[12] Gunther, A. (1864). Catalogue of the fishes in the British Museum, Catalogue of the Physostomi, containing the families Siluridae, Characinidae, Haplochitonidae, Sternoptychidae, Scopelidae, Stomiatidae in the collection of the British Museum, 5, i - xxii + 455 pp.

[13] Hossain,M.S.,Sarker,S.,Sharif,S.M.\&Chowdhury,S.R.(2013 ): New species of stinging catfish $H$. nani from Noakhali, Bangladesh. Vertebrate Zoology, 63 (3): 259-267.
[14] Hubbs, C.L. \& Lagler, K.F. (2004). Fishes of the Great Lakes Region (Smith G.R. ed.), University of Michigan Press, 279pp.- Journal of South Asian Natural History, 3: $113-114$.

[15] IUCN Red List (June, 2007): http://www.iucnredlist.org

[16] Muller J. \& Henle, F.G.J. (1837). Ueber die Gattungen der Plagiostomen. - Archiv für Naturgeschichte, 3: 394 - 401.

[17] Nelson, J. S. (2006): Fishes of the World, John Wiley \& Sons, Inc., p, ISBN 0-471-25031-7

[18] Nelson, J.S. (1994): Fishes of the World. Third edition. John Wiley and Sons, Inc., New York.

[19] Pethiyagoda, R. \& Bahir, M.M. (1998). Heteropneustes microps, a junior synonym of $H$. fossilis (Osteichthyes: Heteropneustidae). - Journal of South Asian Natural History, 3: 113 - 114 .

[20] Pethiyagoda, R. (1991): Freshwater Fishes of Sri Lanka. The Wildlife Trust of Sri Lanka, Colombo.

[21] Pethiyagoda, R. (1994): Threats to the indigenous freshwater fishes of Sri Lanka and remarks on their conservation. Hydrobiologia, 285: 189 - 201.

[22] Satora, L.; Pach, D.; Targosz, D. \& Szkolnicka, B. (2005). Stinging catfish poisoning. - Clinical Toxicology, 43: 893 894.

[23] Wright, J.J. (2009). Diversity, phylogenetic distribution, and origins of venomous catfishes. - Evolutionary Biology, 9: 282.

\section{Author Profile}

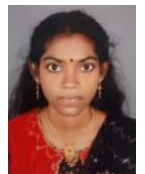

Reenamole.G.R received the B.Sc. degree in Zoology from H.H.M.S.P.B.N.S.S.College for Women, Neeramankara. B.Ed in Natural Science has taken from Govt. Anchal College, Kollam. M.Sc. degree in Zoology took from Mahatma Gandhi College, Thiruvananthapuram. M. Phil in Aquatic Biology and Fisheries from the Department of Aquatic Biology \& Fisheries in the University of Kerala, Kariavattom in 2012. All the degrees were received from the University of Kerala, Thiruvananthapuram, India. She has published 14 research papers and designed a text book of "Vellayani Fish Census- a Field Guide and Report" (Author: Dr. A. Biju Kumar \& Dr. Pramod Kiran R.B) published by Dept. of Aquatic Biology and Fisheries, University of Kerala and Supported by Agency of Development of Aquaculture, Kerala (ADAK) 2013. During 20082009, she worked as a Project Fellow in Central Marine Fisheries Research Institute in Vizhinjum, Thiruvananthapuram, Kerala, India. She now is doing Ph.D in Zoology at Zoology Research Centre, Department of Zoology, Fatima Mata National College, Kollam, University of Kerala, India.

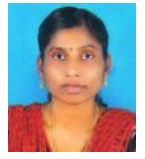

Ambili. T received the B.Sc. degree in Zoology from Sree Narayana Womens College, kollam. M.Sc. degree in Zoology from Fatima Mata National College,Kollam. B.Ed taken in Natural Science and awarded SET also. She has taken DCA. In 2012, she took M. Phil in Aquatic Biology and Fisheries from the Department of Aquatic Biology \& Fisheries in the University of Kerala, Kariavattom. All the degrees were received from the University of Kerala, Thiruvananthapuram, India. She has published 14 research papers. She now is doing Ph.D in Zoology at Zoology Research Centre, Department of Zoology, Fatima Mata National College, Kollam, University of Kerala, India. 